\title{
Cancer stem cells: a new approach to tumor development
}

\author{
Natália Cristina Ciufa Kobayashi ${ }^{1 *}$, Samuel Marcos Ribeiro de Noronha ${ }^{2}$ \\ ${ }^{1}$ Full Teaching Degree in Biological Sciences - Graduate degree in Molecular Biology, United Metropolitan Colleges (FMU), São Paulo, SP, Brazil \\ ${ }^{2} \mathrm{PhD}$ - Department of Allergy and Immunology, University of São Paulo (USP), São Paulo, SP, Brazil
}

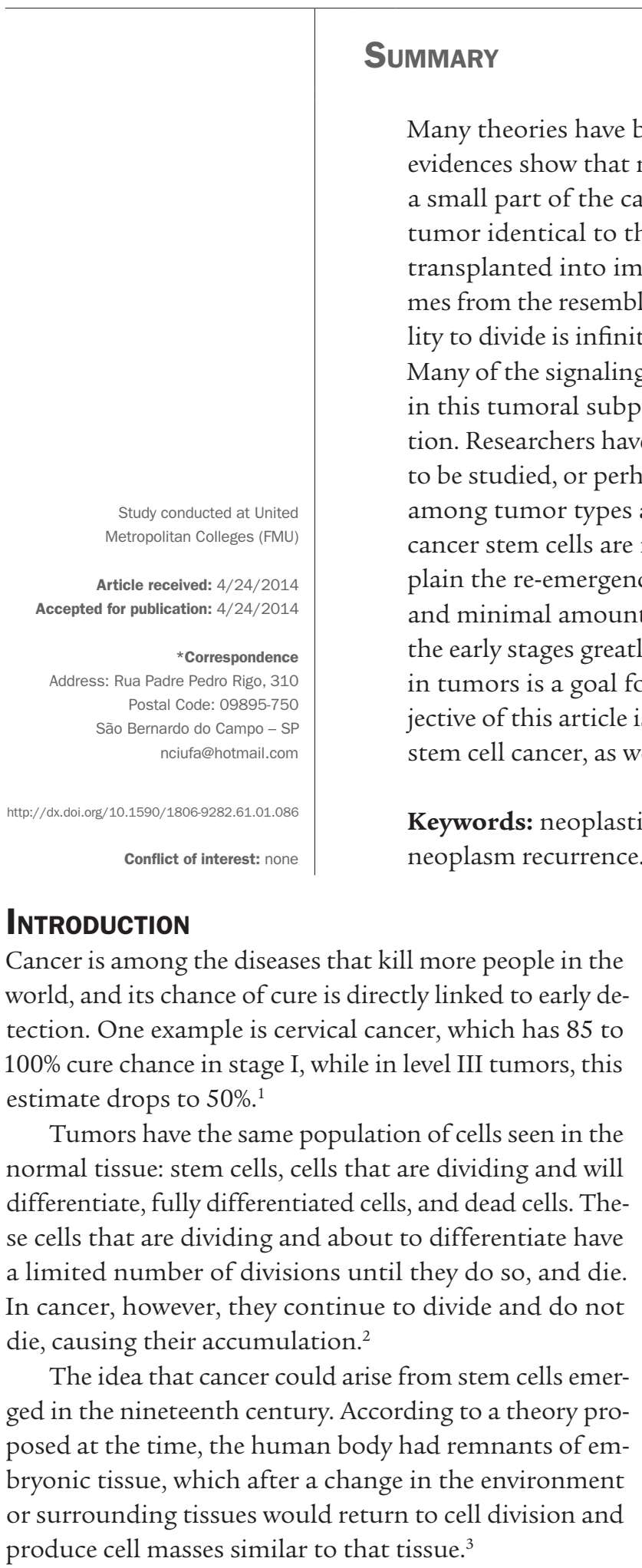

However, this concept was discredited in the twentieth century with the Theory of Dedifferentiation, which states that tumors are derived from the unlimited growth of cells regressing from a more differentiated state to a simpler, pluripotent, state. ${ }^{3}$

The development pattern called stochastic suggests that tumors are homogeneous masses that may be derived from any cell that composes them, provided that the necessary mutations have occurred. New research has shown that cancer development follows a hierarchy where only a subset of tumor cells is responsible for its origin and generate all cell lines forming the tumor. ${ }^{4}$

\section{Discussion}

\section{Origin and characteristics}

The division of normal stem cell is asymmetric, originating a new stem cell (self-renewal) or a cell that will differentiate. This process is highly controlled by several signaling molecules and growth factors. ${ }^{5}$ 
Cancer stem cells are named like this because they present the following properties, very similar to normal stem cells:

1. Self-renewal capacity.

2. Chance to differentiate.

3. Great expression of telomerase.

4. Evasion from apoptosis.

5. Increase in transportation of substances through the membrane.

6. Ability to migrate and, in the case of CSCs, to generate metastases. ${ }^{6}$

Due to these similarities, there are two hypotheses for their emergence: either a) the stem cells themselves would undergo mutation and become cancer stem cells, or b) dedifferentiation of already differentiated cells, providing them pluripotency. There is also a third option that proposes a rare fusion between normal stem cells and other cells. ${ }^{8}$

When dividing, both CSCs and normal stem cells give rise to two different cell types. The first maintains the property of self-renewal. ${ }^{7}$ These are cells that, when taken from a human tumor and transplanted into non-obese, diabetic, immunosuppressed mice (NOD-SCID mice), form a new tumor similar to the original. ${ }^{9}$

The second type is that of tumor cells which are capable of differentiating but unable to initiate a tumor. ${ }^{7}$

\section{Controlled by niche}

Adult stem cells are responsible for tissue maintenance and homeostasis. If there is any damage, for example, they start to divide in order to regenerate the lesion. ${ }^{10}$ But they are not constantly in mitosis. The niche, a microenvironment formed by adjacent cells, must send signals so that these cells can leave their state of dormancy and enter cell division. ${ }^{6}$

Unlike adult stem cells, CSCs have unlimited divisions. ${ }^{10}$

Autocrine and paracrine signaling pathways, such as WNT, Notch, Hedgehog, TGF- $\beta$, and tyrosine kinase receptors are strongly associated with the control of cancer stem cells. ${ }^{11}$

For example, the Hedgehog signaling pathway plays a pivotal role in organogenesis, patterning and maintenance of stem cells. It can act as a morphogen by inducing cell differentiation or as a mitogen, leading to proliferation of precursor cells and mediating the interaction between mesenchymal and epithelial compartments. ${ }^{4}$ This pathway also plays an important role in the maintenance of tumors associated with stromal cells. Its inhibition in stromal cells associated with pancreatic cancer showed suppression of tumor growth. However, inhibi- tion of this pathway in pancreatic cancer cells themselves has not had any effect on the tumor. ${ }^{12}$

The WNT pathway, in turn, controls the proliferation and migration of cells. In patients with colorectal cancer, however, it is dysregulated. High concentrations of $\beta$-catenin are found in the nucleus of tumoral cells that lost expression of E-cadherin. These cells are associated with metastasis and a lower chance of survival. Moreover, nuclear $\beta$-catenin increases the expression of survivin, which promotes cell proliferation and resistance to apoptosis. ${ }^{13}$

The Notch pathway, along with WNT, maintains the homeostasis of stem and progenitor cells by inhibiting their differentiation. Notch is also responsible for the expansion of neural and mammary stem cells. Disorder in this pathway is connected to self-renewal in medulloblastoma tumors. Inhibition of this pathway resulted in CSC apoptosis. ${ }^{13}$

It has also been discovered that specific miRNAs, such as miR-302a, have an important role in the control of pluripotency by activating genes involved in cell cycle, epigenetic modifications, and epithelial-mesenchymal transitions. Researchers have shown that miR-302a expression is capable of causing dedifferentiation of skin cancer cells, proving that miRNAs are also able to reprogram cells into a pluripotent state. ${ }^{11}$

\section{BIOMARKERS OF CANCER STEM CELLS AND THERAPEUTIC APPROACHES}

Cancer stem cells have been found in myeloid leukemia, breast cancer, prostate cancer, ovarian cancer and some types of brain tumors. ${ }^{14}$

Tumor markers such as CA 125 and prostate antigen, for example, are the most commonly used forms to investigate the disease. But they come from differentiated cells in the midst of tumors already formed. ${ }^{6}$ Nevertheless, CSCs are the beginning of cancer, and detection would allow for earlier diagnosis.

Several biomarkers have been used to identify CSCs in many types of cancer: $\mathrm{CD} 34 \mathrm{CD} 38$ - for acute myeloid leukemia; $\mathrm{CD} 44 \mathrm{CD} 24$ and $\mathrm{ALDH}$ for breast cancer; CD133 for the brain; $C D 44 \alpha_{2} \beta_{1}{ }^{\text {high }} \mathrm{CD} 133$ for prostate cancer; CD44 for head and neck; CD133, EpCAM ${ }^{\text {high }} \mathrm{CD} 44$, ALDH1 for colon cancer; ESACD44CD24 and CD133 for pancreas; side population (flow cytometry) for mesenchymal cancer; CD133 for lung; CD90 for liver cancer, ABCB5 for melanomas, and CD133 for ovarian cancer. ${ }^{12}$

However, a universal biomarker for these cells may not exist. Studies have demonstrated that the most widely used marker for brain tumor, CD133, is not present in all tumors, and also that CD133 cells are capable of forming tumors. ${ }^{4}$ 
Based on the principle that all types of cancer have in common an excessive proliferation of affected cells, and that more differentiated cells have a lower rate of division, therapeutic approaches were developed such as induction of differentiation and destruction of these differentiated cells. But none of these approaches can cure cancer completely. ${ }^{5}$ Studies have proven that removing as much as possible of the tumor does not mean cure, because minimum amounts of CSC can lead to disease relapse. ${ }^{10}$

Elimination of cancer stem cells would mean the eradication of the disease, but the biggest challenge is to find treatments that can kill these cells only, without interfering with normal stem cells, since both share several pathways such as those involved in self-renewal. ${ }^{6}$

Recent studies show the feasibility of this approach. For instance, the $\gamma$-secretase enzyme participates in the Notch pathway. An inhibitor of this enzyme was shown to be useful against breast cancer that has the expression of Notch I abnormally high. Another test demonstrated that inhibition of the Hedgehog pathway by cyclopamine causes dramatic regression in various types of tumors. At least for a short period of time, none of these treatments seemed to cause toxicity. ${ }^{6}$

Studies also show that CSCs are resistant to ionizing radiation as used in radiotherapy. Analyzing the cell marker CD133, glioblastoma cells were subjected to radiation. CD133 cells have characteristics attributed to cancer stem cells, and survived at higher dosages compared to most cells, which were $\mathrm{CD} 133$, and were able to repopulate the tumor. Investigation of DNA damage in these two lineages showed that they were similar; but in CD133 cells, the defect was repaired more efficiently and there was less apoptosis. ${ }^{15}$

\section{CSCS AND THE MANY TYPES OF CANCER}

\section{Myeloid leukemias}

In one study, human leukemic cells (acute myeloid leukemia) of CD34CD38 and CD34CD38- lineage were transplanted into mice. The results showed that the presence of leukemic stem cells was greater in CD34CD38 cells. ${ }^{16}$

The researchers also found that leukemia stem cells have a phenotype very similar to those of normal hematopoietic stem cells, but with slight differences. One is that leukemic stem cells, unlike normal stem cells, have CD123 receptors on interleukin-3 $\alpha$ chain. In addition, they also feature the CD33 marker. ${ }^{14}$ Gemtuzumab ozogamicin, an antibody against CD33, conjugated to a toxin called calicheamicin, is being used in clinical trials. Even though the antibody causes proven tumor regression in patients, they are still likely to relapse because, it seems, leukemic stem cells are resistant to calicheamicin. Anti- bodies against $\mathrm{CD} 123$ also avoided grafting of these cells into mice, and decreased tumor load in those with already established disease. ${ }^{16}$

The origin of the leukemic stem cells is still controversial. Since both are capable of self-renewal, it is possible that leukemic stem cells are normal hematopoietic stem cells that have undergone accumulation of mutations. This hypothesis is based on the fact that stem cells have a much longer life than progenitor cells and thus are more likely to accumulate mutations; in addition, they require fewer changes in pathways that regulate self-renewal, so that it becomes unlimited. In progenitor cells, in turn, a mutation must occur first in order to the cell to acquire self-renewal capacity and only then, other changes that would allow for tumorigenic activity. ${ }^{17}$

In Brazil, it is estimated that, in 2014, 5,050 new cases of leukemia occurred in men and 4,320 in women. These values correspond to an estimated risk of 5.20 new cases per 100,000 men and 4.24 for every 100,000 women. ${ }^{18}$

\section{Breast cancer}

In Brazil, breast cancer is the leading cause of death by cancer and the second in the United States. In Brazil, in 2014, 57,120 new cases of breast cancer are expected, with an estimated risk of 56.09 cases per 100,000 women. ${ }^{18}$

In this type of cancer, the tumor is usually localized, but in up to half of the cases, it may develop into metastases. ${ }^{19}$

Cancer stem cells can be identified by various methods: mammosphere formation; flow cytometry; analysis of biomarkers such as CD24, CD44, CD49f and $\mathrm{ALDH}_{1}$; studies with radioactive thymidine and bromodeoxyuridine (BrdU); quiescence (use of PKH26 dye which is retained by quiescent cells); study of side population and positive ALDH cells. ${ }^{20}$

Studies show that there was a fall in the number of deaths from breast cancer in the United States and the world. This is due to early detection using mammography and the development of new drugs such as trastuzumab and aromatase inhibitors. ${ }^{21}$

Although the numbers appear to be promising, the mortality rate among women with metastatic breast cancer has hardly changed over the past decades. The relapse rate of the disease has decreased through the use of therapies, such as chemotherapy, hormonal therapy and HER-2 inhibitors, but the disease recurs in a large proportion of these women. ${ }^{21}$

Since more than half of the tumors have hormonal receptors, hormone treatment is indicated for tumors positive for estrogen or progesterone in the case of patients with no risk of imminent death, and they can be used before or after menopause. For premenopausal women the- 
re is also the option of castration, which can be pharmacological, surgical or radiotherapic. In postmenopausal women, aromatase inhibitors are used as alternatives. ${ }^{19}$

Many studies have demonstrated the survival of CD44/ $\mathrm{CD} 24^{\text {low }}$ cells in tumors treated with chemotherapy. One week after treatment with paclitaxel and epirubicin, widely used in the treatment of this disease, the survival of CSCs capable of generating more tumor cells was observed. That may explain the recurrence of the tumor after treatment with these agents. The same was observed after using docetaxel. ${ }^{22}$

\section{Brain cancer}

Among all types of cancer, brain cancer is the one with the worst outcomes, since there are no risk factors that can be modified to prevent them. Survivors of this form of cancer often have intellectual disabilities due to chemotherapy and radiotherapy. Even tumors classified as benign can lead to death simply by being located at sites that are surgically inaccessible. ${ }^{23}$

Besides the fact that genetic knowledge about brain tumors is still insufficient for the development of new effective therapies, advanced diagnostic imaging techniques to date are not reliable for detecting tumors in early stages. ${ }^{24}$

It is estimated that in Brazil in 2014, 4,960 new cases of cancer of the central nervous system (CNS) occurred in men and 4,130 in women. These numbers correspond to an estimated risk of 5.07 new cases per 100,000 men and 4.05 per 100,000 women. ${ }^{18}$

In adults, the most common forms are gliomas, due to their resemblance to the glial cells that provide support and nutrition to neurons. Average survival for patients is only 15 months. In children, the most common type is that of medulloblastoma, with a slightly longer survival compared to patients with gliomas. ${ }^{24}$

Many studies have shown that brain cancer stem cells were found only among cells that had CD133 marker in glioma and medulloblastoma cells. They can be found at a frequency of $1 \%$ or less among cells of low-risk tumors, and up to $30 \%$ in very aggressive glioblastomas. However, even in the same type of tumor, as in glioblastomas, the frequency of the marker may vary from 5 to $30 \%$ in different patients. ${ }^{23}$

Despite the fact that CD133 is the most widely used marker for identifying brain cancer stem cells, it cannot be regarded as an absolute marker, since many normal cells express this glycoprotein. CD15, a marker of embryonic stem cells in mice, has been used as an alternative, but its use for CSCs identification is unclear, since it is also present in progenitor cells and normal nerve cells. Moreover, its function in normal stem cells and CSCs is not well understood. Other markers such as $\mathrm{A}_{2} \mathrm{~B}_{5}$ have also been used, although their use as markers of CSCs still needs more study. ${ }^{25}$

\section{Prostate cancer}

Prostate cancer is the most common type of cancer diagnosed in men, and the second in terms of number of deaths, second only to lung cancer. ${ }^{26}$

According to INCA, 68,800 new cases of prostate cancer are estimated for Brazil in 2014, which corresponds to an estimated risk of 70.42 new cases per 100,000 men. ${ }^{18}$

Despite recent advances in early detection of the disease, treatment for patients in an advanced or metastatic stage remains ineffective. Most patients initially respond well to androgen ablation therapy because most tumors are androgen-dependent; however, quite often androgen-independent tumors appear, which can lead to metastasis. ${ }^{26}$

Prostate cancer cells of the CD $44 \alpha_{2} \beta_{1}$ CD133 lineage are highly clonogenic and seem to have properties of cancer stem cells. In cells taken from culture and xenograft, CD44 cells have greater expression of genes that confer stem cell characteristics, being more quiescent, tumorigenic and metastatic than CD $44 .{ }^{27}$

\section{Head and neck cancer}

The standard treatment for squamous cell carcinoma of the head and neck is chemotherapy using platinum-based drugs, surgery and radiation therapy. Experiments have shown that $\mathrm{CD} 44$ expression distinguishes a subpopulation of progenitor cells. Follow-up studies revealed that the activity of aldehyde dehydrogenase (ALDH) also marks a population of highly tumorigenic cells. Therefore, both markers began to be used. ${ }^{28}$

Twenty out of thirty CD44 cells implanted generated tumors in immunosuppressed mice, compared to only one out of forty CD44 cells. Some forms of CD44 have been linked to tumor progression and metastasis in this type of cancer. ${ }^{29}$

Conventional chemotherapy is successful in reducing the tumor. However, it is directed to highly tumorigenic cells, and cancer stem cells may remain quiescent for a long period of time, dodging the action of these drugs. Then, they can become active again, differentiate and proliferate, leading to tumor recurrence or even metastasis. A kind of promising treatment to cure squamous cell cancer of head or neck is using chemotherapy and therapy against cancer stem cells, simultaneously. Many studies are being conducted to point out the types of mechanisms that are active in CSCs but not in normal cells, so that such cells can be correctly identified. Another strategy to eliminate cancer stem cells is not to target them directly, but their niche. Using an apoptotic stimulator 
based on caspases, which cleave proteins after an aspartic acid residue and act in cell death, one group eliminated veins associated with a tumor in xenografts and found a reduction in CSCs, suggesting that anti-angiogenic therapies may be highly effective. ${ }^{29}$

\section{Colorectal cancer}

According to estimates, in 2014 there will be 15,070 new cases of colon and rectal cancer in men and 17,530 in women, in Brazil. ${ }^{18}$

Most of the deaths occurred in this type of cancer are due to metastasis to other organs, especially the liver. ${ }^{30}$

Three recent studies provide evidence for the existence of CSCs in this type of cancer. In the first, CD133 cells and cells isolated from seven primary tumors of colon cancer and ten metastases were placed into the renal capsule of NOD-SCID mice. The CD133 cells in tumorigenic population increased from 3.2 to $24.5 \%$, while in normal tissue they increased from 0.4 to $2.1 \%$. In a second study, CD133 cells were grown in vitro as floating colonies or tumor spheres. The analysis of subsequent populations revealed CD133 and CD133 cells, but only the CD133 cells were tumorigenic. It also demonstrated the pluripotent power of CSCs. In the third study, CD44 and epithelial surface antigen were used as stem cell markers, as well as CD166. The tumor was separated, and cells which supposedly initiated the tumor were isolated by flow cytometry and injected into immunosuppressed mice. The result was that 200 to 500 cells were required only for reconstituting a tumor phenotypically equal to that from which the tumor cells were collected. In contrast, cells with low index of epithelial superficial antigen and CD44 were not able to generate tumors. ${ }^{31}$

Research has shown that colon cancer stem cells CD133 produce and use cytokine IL-4 against apoptosis caused by usual chemotherapeutic agents such as 5-fluorouracil and oxaliplatin. ${ }^{32}$

For now, salinomycin, a potassium ionophore, was described as the first compound that can eradicate a tumor, inducing differentiation of CSCs. Exposure of cancer stem cells to bone morphogenetic protein $4\left(\mathrm{BMP}_{4}\right)$ also induces differentiation, making them susceptible to the action of 5-fluorouracil and oxaliplatin. ${ }^{33}$

\section{Pancreatic cancer}

Patients with this type of cancer have an average life expectancy of six months, and only 3-5\% of those affected can survive up to 5 years. ${ }^{34}$

Pancreatic adenocarcinoma cells expressing CD24 and CD44 markers were separated by flow cytometry. Compared to CD24 CD44 cells, CD24CD44 cells presen- ted lower in vitro proliferation, and tumorigenic potential 20 times greater in immunosuppressed mice..$^{35}$

Among solid tumors, administration of drugs in pancreatic cancer is especially difficult, due to its poorly vascularized and poorly perfused structure. The presence of stromal components increases interstitial fluid pressure, hindering drug penetration in the interstitium..$^{35}$

Heterogeneity among patients can also contribute to various types of pancreatic cancer stem cells. Recurring mutations, including KRas, are characteristic of most adenocarcinomas of pancreatic ducts. It is not yet clear whether phenotypically similar CSCs from two patients have the same characteristics and act the same way in the development of the disease. Another issue is that cancer cells can be genetically different in the same individual. ${ }^{36}$

\section{Lung cancer}

In Brazil in 2014, 16,400 new cases of lung cancer are expected among men and 10,930 among women. Cigarette smoking is the major factor in disease development, present in approximately $80 \%$ of cases. Tobacco users are 20-30 times more likely to develop this type of cancer compared to nonsmokers. ${ }^{18}$

The two main types of lung cancer are small cell tumors, and non-small cell tumors (adenocarcinoma, squamous cell carcinoma, large cell lung carcinoma, large cell neuroendocrine lung cancer, bronchoalveolar cancer, and associations of more than one subtype). ${ }^{37}$

The presence of cells with cancer stem cell characteristics was first demonstrated about 30 years ago, when researchers found that only a small portion, less than $1.5 \%$, of cells taken from patients with small cell lung tumors and adenocarcinomas could generate colonies on agar. When these colonies were inoculated into NOD-SCID mice, they generated small cell lung tumors and adenocarcinomas, similar to those where the cells were taken from. As in other types of cancer, some cells from small cell lung tumors and non-small cell lung tumors were found to be CD133, and highly resistant to chemotherapy. However, CD133 cannot be considered as an absolute marker for lung CSCs, since CD133 cells also have self-renewal capacity and generate tumors from xenografts in immunosuppressed mice. Furthermore, in many lung tumors CD133 was not identified. The ALDH marker can also be used to identify lung cancer stem cells. In one study, high concentrations of this marker were linked to a less favorable prognosis in patients with lung cancer, which is consistent with the hypothesis that ALDH lung tumor cells have large concentrations of cancer stem cells. $^{38}$ 


\section{Liver cancer}

Among primary liver cancers, hepatocellular carcinoma is the most common subtype, totaling $70-80 \%$ of cases. Cholangiocarcinoma, which affects the bile ducts within the liver, is the second most common subtype. There are reports of combined tumors, such as hepatocellular-cholangiocarcinoma, expressing features of both hepatocellular and biliary epithelial differentiation, indicating that liver cancer stem cells can be bi-potent. ${ }^{18,39}$

Liver cancer often begins as liver chronic diseases where inflammation and cell regeneration are always occurring. During long and recurring inflammation and regeneration processes, pathophysiological changes can occur that cause these two processes to act initiating and/or promoting liver cancer. Some of these changes include an increase in stem and progenitor cells, accumulation of genetic and/or epigenetic mutations, and changes in the microenvironment. ${ }^{39}$

Recent studies indicate that liver cancer stem cells can originate from progenitor or oval cells in the liver. These cells can act as stem cells, differentiating to hepatocytes or biliary cells after damage caused to the liver, as seen in the treatment with 2 -acetylaminofluorene, subsequent to a partial hepatectomy, a situation in which hepatocytes cannot recover the damaged tissue by themselves. As in other types of cancer, the CD133 marker has been used to identify CSCs from hepatocellular carcinomas; but this biomarker is not fully effective because although few CD133 cells have the property to generate tumors in xenograft, CD133- cells in large numbers also have tumorigenic activity. Thus, other markers have been used, such as CD90, demonstrating that CD90 cells have high tumorigenic potential, unlike CD90- cells. ${ }^{40}$

\section{Melanomas}

The multimolecular drug carrier ABCB5 was identified in melanoma subpopulations and presented high tumorigenic power when $\mathrm{ABCB} 5$ cells were transplanted into NOD-SCID mice. ${ }^{41}$

In one experiment, the researchers found that ABCB5 cells transplanted into immunosuppressed mice were able to generate tumors with $\mathrm{ABCB} 5$ and $\mathrm{ABCB} 5^{-}$lineages, while $\mathrm{ABCB} 5^{-}$xenografts would proliferate at much lower rates and generated $\mathrm{ABCB} 5$ cells only. After administration of anti-ABCB5 antibodies, cytotoxic effect was noted in malignant melanoma primer cells. ${ }^{42}$

Compared to other skin cancers, melanoma has low incidence but high mortality. In 2014, Brazil, 2,960 new cases are expected in men and 2,930 in women. It is more common in fair-skinned populations exposed to solar radiation. ${ }^{18}$
In another essay, melanoma cells with high expression of ALDH were isolated using Aldefluor ${ }^{\circledR}$ kit. Cells incubated in Aldefluor ${ }^{\circledR}$ were taken from stromal cells and dead cells. At the end of the process, the ALDH and $\mathrm{ALDH}^{-}$cells were tested for possible cross-contamination, and the result was that the samples had about 95\% purity. In this assay, cells from nine human melanoma tumors were used, of which 3 primary tumors and 6 metastatic tumors, and 10 xenografts in mice, including 4 primary and 6 metastatic. After analysis, eight of nine patients and eight out of ten xenografts showed discrete subpopulations of ALDH, approximately 0.08 to $1.15 \%$ of live melanoma cells. One in nine patients and two out of ten xenografts expressed subpopulations with ALDH cell concentrations greater than $10 \%$, which exhibited no differences from other cells and mixed to them without apparent separation. ${ }^{43}$

Despite all the evidence, a marker of melanoma cancer stem cells capable of generating cells with and without tumorigenic capacity has not yet been found. ${ }^{44}$

However, there are still doubts whether the development of melanoma follows the model of cancer stem cells. Some groups question the results obtained in xenograft studies. According to them, aspects such as study duration, degree of immunodeficiency in mice receiving xenografts, and the extracellular environment at the site where the cells will be transplanted into can all interfere with tumor formation and growth. ${ }^{41}$

\section{Ovary cancer}

In 2014 in Brazil, 5,680 new cases of ovarian cancer are expected. ${ }^{18}$

The first way to isolate stem cells from ovaries was by collecting fluid from ovarian tumors and staining the cells with Hoechst 33342. Stem cells have the property to remove hazardous dyes, and thus their cytoplasm contains lower concentrations of Hoechst 33342 compared to other cells when subjected to flow cytometry to assess fluorescence. Ovarian CSCs are the so called side population in this study. ${ }^{45}$

One way to eradicate ovarian CSCs is to induce them to differentiate, which causes them to lose their stem cell characteristics. Recently, the use of carboplatin conjugated with retinoid compounds was able to reduce the growth of ovarian stem cells. In addition, some unsaturated fats, including palmitoleic, oleic and linoleic acids, can induce ovarian CSCs lineages to turn into cells similar to adipocytes. More research is needed to understand the regulation of differentiation so that new drugs are more effective. ${ }^{45}$

There are also reports that the recurrent use of the drug Cisplatin seems to generate a cell line resistant to chemo- 
therapy with stem cell characteristics, suggesting that CSCs may arise after successive rounds of chemotherapy. ${ }^{46}$

\section{Conclusion}

Despite much evidence pointing to the existence of cancer stem cells, this subject is controversial and needs to be studied. This model is the one that best explains the high relapse rates of the disease in many types of tumor. However, some aspects still need to be clarified; for instance, if there are differences in the growth of a tumor, even from human cells, when grafted into immunosuppressed mice, and to what extent the degree of immunodeficiency interferes with propagation of the cells. Also, there are doubts if the amount of inoculated cells can also affect the outcome of the study.

Cancer, in most cases, is effectively treated if detected early. The existence of biomarkers for CSCs would be helpful for diagnosis, as well as to eradicate this disease. But the studies presented so far are not completely conclusive, since each marker may vary among patients and according to the type of cancer.

Regarding therapy, the combined use of drugs that induce differentiation and eliminate already differentiated cancer cells is promising. There is also the option to attack the microenvironment that supports these cells, either by preventing angiogenesis, or interfering in signaling pathways, not yet fully understood in CSCs. However, since any remaining cancer stem cells could cause relapse of the disease, we need to know more about their identification, as well as what happens in their signaling pathways and what does not happen in normal stem cells, what gives them this uncontrolled pluripotent power, so that future drugs can target CSCs only, and not healthy stem cells, which are fundamental to maintain the human body.

\section{CSCS AND CANCER DETECTION}

Many tumors produce substances that are used as tumor markers in cancer diagnosis. However, the assessment of these markers alone does not lead to conclusion that the patient has the disease. The use of biomarkers for CSC would be an additional alternative for detection. Furthermore, high levels of these tumor markers appear when the tumor is already installed, while the use of cancer stem cells would allow detecting the tumor at a very early stage.

\section{CSCs AND CANCER DIAGNOSIS}

The knowledge of cancer stem cells and their markers can help differentiate tumors by type, taking into account their location. It is also possible to evaluate the degree of tumor aggressiveness according to the phenotype of the- se cells. Taking the example of breast cancer, CD44CD24cells are more invasive and have greater proliferative potential than that of CD44CD24 cells.

Furthermore, the screening of CSCs could be used in the diagnosis of possible metastasis since these cells are highly tumorigenic and have migratory capacity.

\section{CSCs AND CANCER SIZE}

Knowing that these cells are in a more quiescent state, making them highly resistant to chemotherapy and radiotherapy, which are precisely the most used treatments today, will assist in developing more effective drugs that can affect the origin of disease.

This will also contribute to improved quality of life of patients because current treatments with chemotherapy not only cause great distress for patients, but also do not mean cure. Not to mention that, often, these drugs affect not only the diseased cells, but also healthy ones.

Once these cells were identified, drugs targeted to them would eradicate the tumor without allowing recurrence of cancer.

\section{CSCS IN CANCER PREVENTION}

Knowing the signaling pathways altered in cancer stem cells, the formation of new tumors could be prevented with drugs able to correct these pathways.

Still regarding cancer recurrence, periodic examinations would be able to detect remnants of these cells, which could be destroyed even before tumor formation, significantly increasing the chances of cure.

In patients with a family history of the disease, and those with habits that increase the chance of disease, such as smoking in the case of lung cancer, detection of these cells could be an investigation performed periodically, thus aiding disease prevention.

\section{Resumo}

Células-tronco de câncer: um nova abordagem do desenvolvimento tumoral.

Diversas teorias buscam explicar a origem do câncer. Atualmente, há evidências de que nem todas as células tumorais têm poder de iniciar um tumor. Apenas uma pequena parte das células cancerígenas, chamadas de células-tronco de câncer (do inglês cancer stem cells - CSC), é capaz de iniciar um tumor idêntico ao original quando retirada de tumores humanos e enxertada em camundongos imunossuprimidos. Essas células foram assim denominadas por suas semelhanças com células-tronco normais, exceto pelo fato de que sua capacidade de dividir-se é infinita. Essas células também recebem in- 
fluência de seu microambiente. Várias vias de sinalização, como WNT, NOTCH e Hedgehog, estão alteradas nessa subpopulação tumoral, contribuindo também para a desregulação de sua proliferação. Pesquisadores descobriram vários marcadores para as CSC, porém ainda há muito a ser pesquisado, ou talvez nem exista um marcador universal, já que eles variam entre cada tipo de tumor e até de paciente para paciente. Foi constatado também que as CSC são resistentes à radioterapia e à quimioterapia, podendo explicar o reaparecimento da doença, visto que, além de não eliminá-la completamente, quantidades mínimas das CSC podem repovoar um tumor. Como o diagnóstico em estágios iniciais aumenta muito as chances de cura do câncer, a identificação das CSC em meio a um tumor é alvo para o desenvolvimento de tratamentos mais eficazes. O objetivo deste artigo é discutir a origem do câncer segundo a teoria das CSC, bem como seus marcadores e as terapias utilizadas em seu tratamento.

Palavras-chave: células-tronco neoplásicas, marcadores biológicos de tumor, camundongos SCID, recidiva local de neoplasia.

\section{REFERENCES}

1. Instituto Brasileiro de Controle de Câncer. IBCC. Dúvidas frequentes. [cited on 3/25/14]. Available from: http://www.ibcc.org.br/duvida/especialidadesmedicas/ginecologia/2/20/.

2. Sell S. Stem cells and cancer: an introduction. In: Majumder S, editor. Stem cells and cancer. New York: Springer; 2009. p. 1-26

3. Sell S. On the stem cell origin of cancer. Am J Pathol 2010; 176:2584-94.

4. Ebben JD, Treisman DM, Zorniak M, Kutty RG, Clark PA, Kuo JS. The cancer stem cell paradigma: a new understanding of tumor development and treatment. Expert Opin Ther Targets 2010;14:621-32

5. Li L, Neaves WB. Normal stem cells and cancer stem cells: the niche matters. Cancer Res 2006;66:4553-7.

6. Wicha MS, Liu S, Dontu G. Cancer stem cells: An old idea - A paradigma shift. Cancer Res 2006;66:1883-90.

7. Soltysova A, Altanerova V, Altaner C. Cancer stem cells. Neoplasma 2005;52:432-40.

8. Li F, Tiede B, Massagué J, Kang, Y. Beyond tumorigenesis: cancer stem cells in metastasis. Cell Res 2007;17: 3-14.

9. Vermeulen L, Sprick MR, Kemper K, Stassi G, Medema JP. Cancer stem cells - old concepts, new insights. Cell Death Differ 2008;15: 947-58

10. Baccelli I, Trumpp A. The evolving concept of cancer and metastasis stem cells. J Cell Biol 2012;198:281-93.

11. Li Y, Laterra J. Cancer stem cells: distinct entities or dynamically regulated phenotypes? Cancer Res 2012;72:576-80.

12. O'Brien CA, Kreso A, Jamieson HM. Cancer stem cells and self-renewal. Clin Cancer Res 2010;16:3113-20.

13. Subramaniam D, Ramalingam S, Houchen CW, Anat S. Cancer stem cells: a novel paradigm for cancer prevention and treatment. Mini Ver Med Chem 2010;10:359-71.

14. Schulenburg A, Ulrich-Pur H, Thurnher D, Erovic B, Florian S, Sperr WR, et al. Neoplastic stem cells: a novel therapeutic target in clinical oncology. Cancer 2006;107:2512-20.

15. Rich JN. Cancer stem cells in radiation resistance. Cancer Res 2007;67:8980-4.

16. Horton SJ, Huntly BJP. Recent advances in acute myeloid leucemia stem cell biology. Haematologica 2012;97: 966-74.

17. Passegué E, Jamieson CHM, Ailles LE, Weissman IL. Normal and leukemic hematopoiesis: are leukemias a stem cell disorder or a reacquisition of stem cell characteristics?. Proc Natl Acad Sci U S A 2003;100(Suppl 01):11842-49.

18. Instituto Nacional de Câncer José Alencar Gomes da Silva (INCA). Estimativa 2014 - Incidência de Câncer no Brasil. Available from: <http://www.inca. gov.br/estimativa/2014/sintese-de-resultados-comentarios.asp>. Website visited on Mar 7, 2014.

19. Saad ED, Bromberg S, Katz A, Simon SD. Inibidores da aromatose no câncer de mama: da doença metastática ao tratamento adjuvante. Rev Bras Cancerol 2002;48:555-67.

20. Britton KM, Kirby JA, Lennard TWJ, Meeson AP. Cancer stem cells and side population cells in breast cancer and metastasis. Cancers 2011;03:2106-30

21. Kakarala M, Wicha MS. Implications of the cancer stem-cell hypothesis for breast cancer prevention and therapy. J Clin Oncol 2008;26:2813-20.

22. Economopoulou P, Kaklamani VG, Siziopikou K. The role of cancer stem cells in breast cancer initiation and progression: potential cancer stem celldirected therapies. Oncologist 2012;17:1394-1401.

23. Dirks PB. Brain tumour stem cells: the undercurrents of human brain cancer and their relationship to neural stem cells. Philos Trans R Soc Lond B Biol Sci 2008;363:139-52.

24. Rich JN, Eyler CE. Cancer stem cells in brain tumor biology. Cold Spring Harb Symp Quant Biol 2008;73:411-20.

25. Cheng L, Bao S, Rich JN. Potential therapeutic implications of cancer stem cells in glioblastoma. Biochem Pharmacol 2010;80:654-65.

26. Lang SH, Frame FM, Collins AT. Prostate cancer stem cells. J Pathol 2009;217:299-306.

27. Chen X, Rycaj K, Liu X, Tang DG. New insights into prostate cancer stem cells. Cell Cycle 2013;12:579-86.

28. Zhang Z, Filho MS, Nör JE. The biology of head and neck cancer stem cells. Oral Oncol 2012;48:1-9.

29. Krishnamurthy S, Nör JE. Head and neck cancer stem cells. J Dent Res 2012; 91:334-40.

30. Sanders MA, Majumdar APN. Colon cancer stem cells: Implications in carcinogenesis. Front Biosci (Landmark Ed) 2011;16:1651-62.

31. Huang EH, Wicha MS. Colon cancer stem cells: implications for prevention and therapy. Trends Mol Med 2008;14:503-09.

32. Fanali C, Lucchetti D, Farina M, Corbi M, Cufino V, Cittadini A, et al. Cancer stem cells in colorectal cancer from pathogenesis to therapy: controversies and perspectives. World J Gastroenterol 2014;20:923-42.

33. Puglisi MA, Tesori V, Lattanzi W, Gasbarrini GB, Gasbarrini A. Colon cancer stem cells: controversies and perspectives. World J Gastroenterol 2013; 19:2997-3006.

34. Iovanna J, Mallmann MC, Gonçalves A, Turrini O, Dagorn JC. Current knowledge on pancreatic cancer. Front Oncol 2012;02:01 AM-24.

35. Li J, Wientjes G, Au JL. Pancreatic cancer: pathobiology, treatment options, and drug delivery. AAPS J 2010;12:223-32.

36. Penchev VR, Rasheed ZA, Maitra A, Matsui W. Heterogeneity and targeting of pancreatic cancer stem cells. Clin Cancer Res 2012;18:4277-84.

37. Larsen JE, Minna JD. Molecular biology of lung cancer. Clin Chest Med 2011;32:703-40.

38. Sullivan JP, Minna JD, Shay JW. Evidence for self-renewing lung cancer stem cells and their Implications in tumor initiation, progression, and targeted therapy. Cancer Metastasis Rev 2010;29:61-72.

39. Yamashita T, Wang XW. Cancer stem cells in the development of liver cancer. J Clin Invest 2013;123;1911-8.

40. Wang B, Jacob ST. Role of cancer stem cells in hepatocarcinogenesis. Genome Med 2011;3(2):11.

41. Shackleton M, Quintana E. Progress in understanding melanoma propagation. Mol Oncol 2010;4:451-7.

42. Schatton T, Murphy GF, Frank NY, Yamaura K, Waaga-Gasser AM, Gasser $\mathrm{M}$, et al. Identification of cells initiating human melanoma. Nature 2008; 451:345-9.

43. Luo Y, Dallaglio K, Chen Y, Robinson WA, Robinson SE, McCarter MD, et al. ALDH1A isozymes are markers of human melanoma stem cells and potential therapeutic targets. Stem Cells 2012;30:2100-13.

44. Schatton T, Frank MH. Cancer stem cells and human malignant melanoma. Pigment Cell Melanoma Res 2008;09:39 PM-55.

45. Zhan Q, Wang C, Ngai S. Ovarian cancer stem cells: a new target for cancer therapy. Biomed Res Int 2013;2013:916819.

46. Kwon MJ, Shin YK. Regulations of ovarian cancer stem cells or tumorinitiating cells. Int J Mol Sci 2013;14:6624-48. 